\section{Doctor and death}

Ultimately the doctor has to face the reality of death with his patient. The death of human beings is not the perishing of animals. Clearly one answer is belief in life after death, and, in its authentic presence, death assumes a different meaning. But for all of us, believers or not, death has universal threats. It is not death we are afraid of. We have no knowledge of what death is. But we do have knowledge of the fear of non-being. The terror that some patients have of going to sleep is exactly that. It is the terror of ceasing to be. There is the pain of the loss of those we love and who love us. There is the fear of becoming helpless, impotent, and redundant in life.

Very often the debate around death is whether the patient should be told or not. Clearly some patients would be devastated and overcome by the knowledge. But, whether we inform or not, the task of the doctor is to make the life of the patient as full as possible until the last moment. The challenge of death is to face it and live fully until the end.

\section{Faith and practice}

In conclusion, we have to recognise that there is a small band of believing doctors who attend church and practise their faith. There is a larger number of doctors for whom religious life and practice are unacceptable, but God remains to a variable degree a reality, an ultimate power, latent and hidden. There is a much higher proportion for whom God is a shrouded mystery, clothed in agnosticism, neither denied nor confirmed, nor totally rejected. Finally there is a small minority who are committed atheists but for whom pain, suffering, and death have no satisfactory answers. Our patients also share this multiple confusion.

Instead of our all going our separate ways we have to converge. Those of us who are practising our faith actively must recognise that our faith is respected but the practice of it in church is of no interest to others. Those of us who neither practise nor overtly believe but have a sense of the holy and the infinite have to recognise that the practice of medicine demands recognition of this; and those who have made up their minds through atheism and agnosticism have also to recognise that this is their right and it works for them but not for everyone else.

Just as there is an effort to unite in ecumenism, both believers and unbelievers must recognise the common predicament, and the confusion of the way ahead in our society. We need to work through those aspects of human experience which can transform the ordinary into the extraordinary and can help discern the mystery of the beyond, because the art of healing demands this ultimate value of the transcendental, which means going beyond. In this paper I have tried to indicate how the doctor, acting in the triple capacity of prophet, uses ordinary experiences where the human meets the beyond in an encounter of love.

\title{
Miracles of healing in Anglo-Celtic Northumbria as recorded by the Venerable Bede and his contemporaries: a reappraisal in the light of twentieth century experience
}

\author{
REX GARDNER
}

The vigorous hybrid culture of Briton and Angle ${ }^{2}$ blossomed in the seventh century into the amazing Northumbrian golden age whose artefacts still astonish and delight us. ${ }^{3}$ Its stimulus was the reintroduction of dynamic Christian faith by dedicated Celtic missionaries. ${ }^{4}$ Despite its defeat in 664 by the Roman party, the Celtic faith long remained pervasive, ${ }^{5}$ completely shaping the life of Cuthbert and determining the private spirituality even of its arch opponent Wilfrid. ${ }^{6}$

We know that Celtic monks supplied medicines ${ }^{7}$ and that surgery was practised, perhaps by clerics $^{8}$ as well as laymen. ${ }^{9}$ Miraculous healings, however, loom largest in contemporary records. They have been conveniently catalogued by Highfield. ${ }^{10}$ In later centuries "miracles" were to degenerate into "wonders" and to become as important for the curriculum vitae of the potential saint as are publications for the aspiring senior registrar in modern medicine. In this springtime of the faith, however, miracles were not wonders but "signs" of the power of God.12

Some writers have laughed at miracle. A nineteenth century churchman wrote "If Bede may be credited Cuthbert's only amusement (on the Farne Islands) must have been the performance of miracles ... which notwithstanding their absurdity were duly credited and implicitly believed for centuries."13 A more recent historian has written of "benevolent magic." ${ }_{14}$

Presidential address to the Newcastle and Northern Counties Medical Society October 1982 (revised).

Sunderland District General Hospital, Sunderland SR4 7TP

REX GARDNER, FRCOG, consultant obstetrician and gynaecologist
The denial of miracle, however, poses three problems. Firstly, Bede tells us in the introduction to his Vita $S$ Cuthberti, in which so many of these accounts appear, that it was read aloud to, and approved by, Cuthbert's community at Lindisfarne ${ }^{15}$ at a time when at least five of those he named therein as first hand witnesses of the miracles were still alive. ${ }^{16}$

The second difficulty is of accounting for the stature of Cuthbert, who has dominated our northern traditions for 1200 years. Three centuries after his brief bishopric King Athelstan of Wessex made pilgrimage to his shrine at Chester-le-Street to present rich treasures. If we exclude the miraculous from his story, of the 46 chapters in his biography we are left with only six (chapters 9, 16, 26, 37, 39, 40).

The greatest difficulty, however, is Bede's stature as a historian, a reputation which continues to be enhanced, ${ }^{17}$ yet in whose works miraculous healings are inextricably interwoven.

Bede's stories of miracles are seen by some as the chief obstacle to sympathy and rapport with him. ${ }^{6}$ Attempts are therefore made to explain them away as due to his different interpretation of history ${ }^{18}$ or his view of the function of facts. ${ }^{19}$ As well as his need to show Christ to be as powerful as the old pagan lords, it is suggested that we should recognise three men in Bede: the historian, the hagiographer, and the theologian. ${ }^{20}$ These are distinctions he would surely not have allowed in view of his claim in the preface to his Historiam Ecclesiasticum Gentis Anglorium to have written "in accordance with the principles of true history." $21-23$

The dilemma has been critically summarised by Meyveart. The modern scholar is above believing in miracles, in fact from 
his view point "scholarship" and "belief in miracles" are mutually exclusive terms. ${ }^{24}$ It is therefore understandable that in a study of Anglo-Saxon medicine Bonser has described faith healing as "that dangerous field, placed between theology and medicine, that no one has dared thoroughly to explore." ${ }^{25}$ It seems to me that such an exploration is timely. Bonser's use of the words "risk" and "dared," however, proved to be significant.

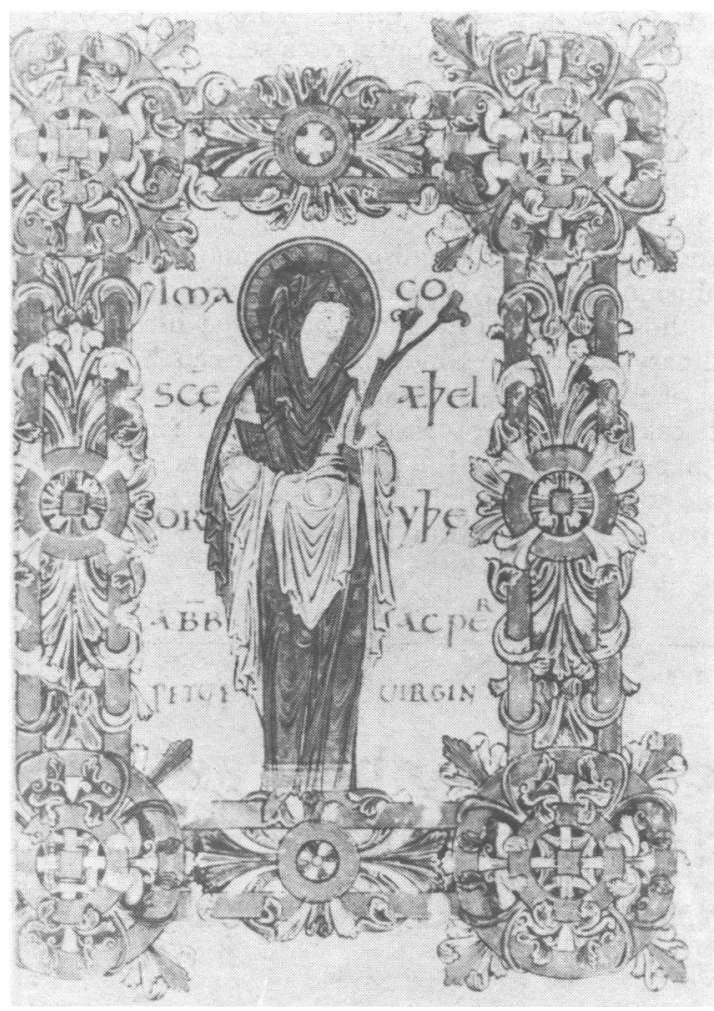

An early surgical patient, $S$ Etheldreda, virgin wife of King Ecgfrith of Northumbria. (British Library MS Additional 49598, folio 90v. Used by permission of the British Library.)

Firstly, of course, the danger of academic suicide. So far as I have been able to discover, no Bedan scholar in recent times has asked that simple question which seems the obvious one to us in medicine. Were these patients healed as described or not? Secondly, is it a useful search ? Can miracles ever be proved?

\section{Case 1}

This child was the second born to healthy parents. He thrived for the first eight months, gaining weight consistently on the 75th centile. At eight months he developed measles, from which he never made a full recovery. Over the next three months he gradually became more apathetic, anorexic, and dyspnoeic. He lost weight from 8.8 to $7.4 \mathrm{~kg}$.

He was admitted to the Royal Victoria Infirmary, Newcastle upon Tyne, in August 1977 at 11 months of age, a wasted, miserable little scrap, severely dyspnoeic at rest, with pronounced lower costal and intercostal recession. Chest radiograph showed diffuse confluent mottling with a small right pneumothorax. He was treated initially with antibiotics, to which there was no response, and a definitive diagnosis of advanced fibrosing alveolitis was established by biopsy of the lung. He was treated for six weeks on high dosage corticosteroids without improvement and for a further six weeks on corticosteroids combined with azathioprine, again without improvement. Blood gas analyses over this period of three months showed progressive deterioration Oxygen pressure $\left(\mathrm{PO}_{2}\right)$ was $5.1 \mathrm{kPa}(38 \mathrm{~mm} \mathrm{Hg})$ at the end of this course of treatment.
At this point his mother was told that as there had been no response whatsoever to conventional treatment, it was thought the disease was likely to be progressive and the prognosis was hopeless. He was discharged home on maintenance prednisolone $10 \mathrm{mg}$ on alternate days.

The child's general practitioner was aware that a nearby pentecostal pastor was preparing himself for a healing service. With the approval of Professor Webb he therefore suggested to the parents that they take the child along. They had no strong affiliation to the Church. He was taken to the service of healing at Heaton Pentecostal Church on 26 February 1978

Five days after the service he was taken back to the Royal Victoria Infirmary where he appeared slightly happier and more ready to play. Two weeks later he was definitely a stronger, happier, more active child, able to pull himself up to stand for the first time in more than four months. From that point he made steady, consistent progress as shown by his weight chart and successive blood gas analyses. At 2 years 3 months his $\mathrm{Po}_{2}$ was $8.3 \mathrm{kPa}(62 \mathrm{~mm} \mathrm{Hg})$ and at 2 years 11 months $10.5 \mathrm{kPa}(79 \mathrm{~mm} \mathrm{Hg})$. He has been followed up since then and when last seen at the age of 5 years 2 months (November 1981) he was a perfectly normal boy with weight just below the 50th centile. (J K G Webb and I V Longfield, personal communications.)

The prognosis for fibrosing alveolitis starting in the first year of life is almost uniformly fatal. It is that word "almost," underlined by Professor Webb in the last line of his case summary, which makes difficult any attempt ever to prove miraculous healing. There is no doubt in his mind, or in that of the general practitioner concerned, that this was the work of God, and it has been locally talked about as "miraculous." The diagnosis is not in doubt, but medicine knows few absolutes, and it would be impossible to refute the challenge that this was a case of inexplicable spontaneous remission.

Even dramatic evidence may not be sufficient.

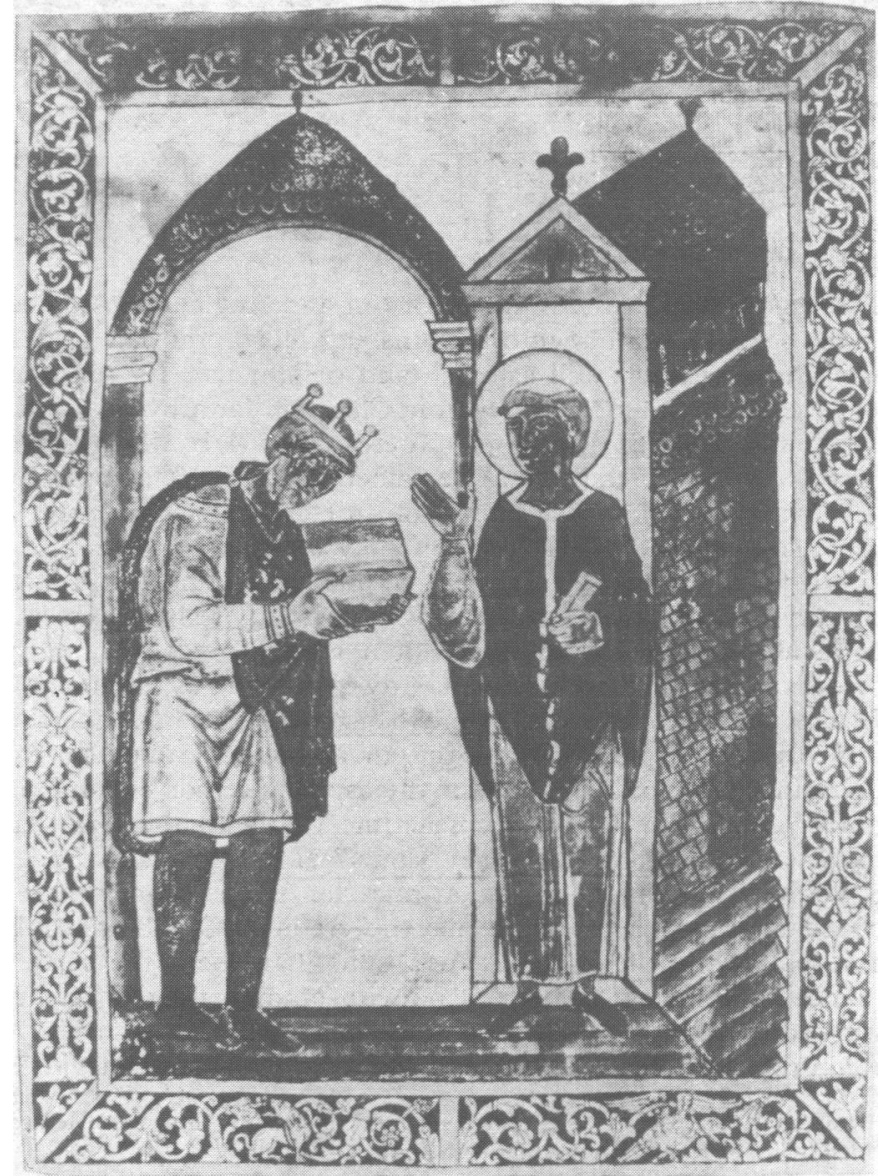

King Athelstan presenting Bede's Life of Cuthbert at the tomb of Cuthbert. (By permission of the Master and Fellows of Corpus Christi College, Cambridge.) 


\section{Case 2}

A young trainee general practitioner became ill suddenly in January 1975 with meningococcal septicaemia with meningitis and was admitted next day moribund to hospital with a diagnosis of the Waterhouse-Friderichsen syndrome. No such case had ever survived in that hospital. That evening groups praying for her in Rhyl, Llandudno, Caernarfon, and Bangor independently but simultaneously believed that their request that she might be healed with no residual disability had been granted. At that same time, $830 \mathrm{pm}$, there was a sudden improvement in her condition, though it was four days before she regained consciousness. Physicians were unable to explain how her chest $x$ ray film, which had showed estensive left sided pneumonia with collapse of the middle lobe, could, 48 hours later, show a normal clear chest. The ophthalmologist saw and photographed a central scotoma in the left eye caused by intraocular haemorrhage affecting the macula, and assured the patient that there was permanent blindness in that eye. Her faith that God had promised her that she would be made "completely whole" 26 was quite reasonably met with his, "You have got to face medical facts." When she did in fact develop perfect vision in that eye, and no residual intraocular disease could be found, he was understandably left unable to offer any explanation, and could only say, "Do you realise you are unique?"

While the patient and her friends ascribe her complete return to full normality to the gracious work of God, the hospital consultants have shown her at postgraduate meetings as "the one that got away." Despite the fact that the four consultants who saw her on admission remain confident as to their diagnosis, its accuracy is called in doubt by those unable to explain her survival (Rhiannon Lloyd, personal communication).

It will be clear therefore that even in well documented cases where patients and doctors are available for questioning and medical records can be examined, proof of miraculous cure is probably impossible.

A further risk in this search is that as there can be no hard data from Anglo-Saxon times, such as was possible in the cases just detailed, the search will be fruitless.

A new line of approach, however, has been suggested by a passage in the most recent life of Columba. Finlay writes, "It is right to be cautious about incredulity. We live in an age of doubt when even the churches look with a critical eye on miracles. Yet I have been told that when modern missionaries left some gospel books behind in Ethiopia and returned many years later, they found not only a flourishing church, but a community of believers among whom miracles like those mentioned in the New Testament happened every day-because there had been no missionaries to teach that such things were not to be taken literally." 27

If, following Finlay's hint, we could find present day incidents similar to those recorded by Bede and his contemporaries, the situation would be altered. Though we will not be able to prove that miracles have occurred, it should be possible to show that the direct intervention of God was the most reasonable explanation of the facts as they saw them.

As we have already noted there are contemporary cases worth pondering. That there is a new climate is undeniable. The 1981-2 conference of the Ecclesiastical History Society was devoted to "The Church and healing" because of "the remarkable revival of concern with healing in the churches today." 2.

What is there new in our day that brings such cases to light and justifies such a quest? Why is it that miraculous healing is now a subject that will not go away and has to be considered?

The Church is always being renewed. We now have a new springtime in which there is an understanding that the New Testament gifts of the Holy Spirit, evidenced at Pentecost, are intended to be the experience of the Church today. After earlier evidences the start of the modern pentecostal movement is usually placed in Los Angeles in 1906. ${ }^{29}$ Since 1956 it has spread into all the mainline denominations, notably within the Roman Catholic Church since 1967. ${ }^{30}$ Among these gifts (the charismata) is the gift of healing.

Although for the past half century there has been a valuable new understanding of the Church's participation in healing and health in its deepest sense, ${ }^{3132}$ and of the need for cooperation between religion and medicine, it is largely to the charismatic renewal we must look for expectation and experience. ${ }^{33}$ Those actively working in such healing ministry have produced a number of accounts, mostly anecdotal but with a noteworthy study by a Roman Catholic priest. ${ }^{34}$ There have been many who have doubted the genuineness of these healings; in 1974, however, its panel of doctrine reported to the General Assembly of the Church of Scotland, "The Panel concluded that certain extraordinary phenomena do occur, such as speaking in tongues and divine healing. They have to be accepted as facts. ${ }^{35}$

Wearmouth, now part of Sunderland, occupies a central place in the geography of Bedan studies. It was here that Benedict Biscop founded his monastery on land given by King Ecgfrith. Whether or not Bede was born in Sunderland has been the subject of discussion, ${ }^{36}$ but it was to the monastery of St Peter that he came as a boy. The lower part of the tower and the west doorway of the existing church are those he used. In Britain it was here in Monkwearmolth that the first breath of the modern pentecostal movement occurred in 1907 in the Parish Church of All Saints, 600 metres from St Peter's Church. ${ }^{37}$ Even closer to St Peters are Baptist, ${ }^{38}$ Pentecostal, and Roman Catholic churches, each of w'ich has been affected by the charismatic renewal. In her reconsideration of the miracle stories used by Bede, Benedicta Ward repeatedly uses the concept that Bede looked at these miracles from the inside. ${ }^{12}$ This phrase highlights the new situation that now obtains.

As we set about our examination of some of the seventh century healing miracles the problems encountered in a critical examination of the records may be shown by an example.

Some time ago, my post contained a circular letter for lay readership headed "Pennell Memorial Hospital, Bannu, NWFP, Pakistan. 21.5.82." It is a long letter of 84 typed lines including the lines which read:

"And here is Kamro who knows that Jesus has saved her. She had a profuse haemorrhage caused by a clotting defect in the blood after a caesarean section last Sunday. This condition responds only to infusions of triple or quadruple strength plasma and fancy drugs in England. Here, where these things are not available, it responds to the prayer of faith in Jesus's name, and I suppose the meagre two pints of blood donated by her brothers, one of whom is a professional footballer, helped to keep her strength up as her own blood poured alarmingly into the bed. Her premature baby daughter, lying in the blue painted cot at the foot of the bed is absolutely sweet and doing very well."

If this were part of some newly discovered early document, a number of questions would occur to the scholar. The paper is good quality duplicating stock, well and evenly inked, while the

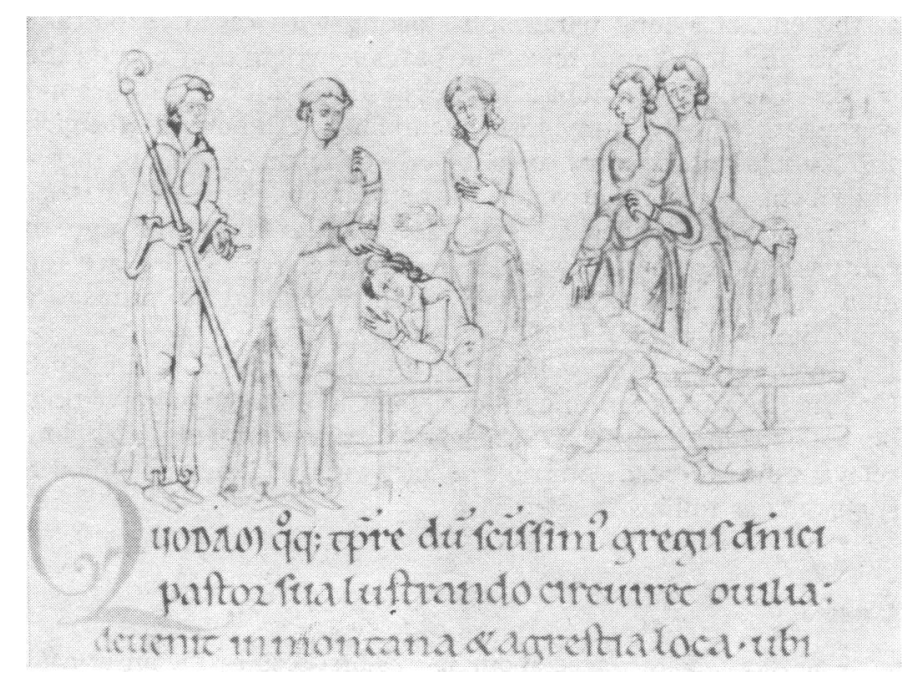

The prayer of St Cuthbert cures a gravely ill youth. (Vita $S$ Cuthberti: 32). University College Oxford. MS 165 Bodleian Library. (By permission of the Master and Fellows of University College.) 
signature "Ruth" is typed. Is this in fact likely to be of overseas origin? Were the envelope to be found it would confirm that the letter was posted in England. Is it then likely to be a forgery? Probably not, as four visitors are named who could be interrogated, one being the British ambassador. But can we be sure that the original letter has been accurately copied ? Could it not be that some intermediary in Britain has attempted to stir up interest by "improving" on facts?

Granted that the account should prove to be genuine then inevitably the story itself requires scrutiny. Most blood trans-

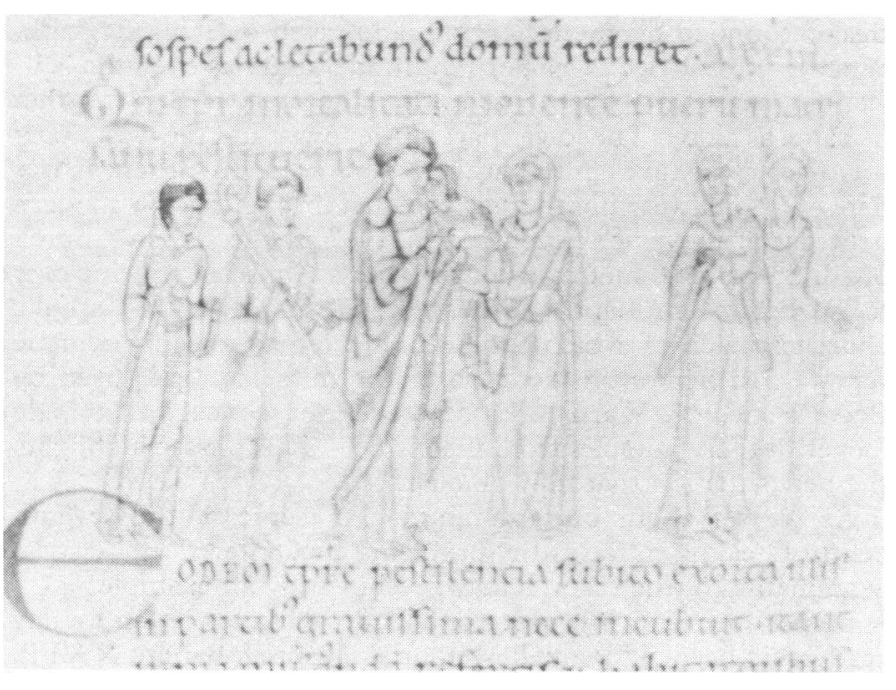

St Cuthbert restores a plague stricken boy, cured, to his mother. (Vita $S$ Cuthberti: 33). University College Oxford. MS 165 Bodleian Library. (By permission of the Master and Fellows of University College.)

fusions given to our patients are of two pints, so would not these accounted for Kamro's recovery? The noteworthy problem is that of the clotting defect. How soundly based was this diagnosis in the presumed absence of a haematological laboratory? We are forced then to rely on a clinical diagnosis. Can we assume that the doctor was sufficiently trained to make this accurately? Most missionary doctors have to perform caesarean sections, but few of them are trained specialist obstetricians, and one cannot expect a missionary doctor to have specialist skills in all medical disciplines. (I write with feeling, having been a missionary doctor.)

The story begins to look unconvincing. The scholar then will ask why this story was included in the letter. The account appears at the end of a long paragraph starting with recent expatriate visitors and detailing three of the patients whom they met on the wards. The first patient had had her second stillbirth, the second was a pathetically skinny and anaemic little Afghan refugee girl, and Kamro was the third. Was it perhaps felt necessary to introduce a cheerful counterweight to the previous depressing cases?

This account looked at as scholars look at sixth and seventh century stories therefore appears unimpressive. There are too many holes in it; we can see why Stenton coined the phrase "a mere tissue of miracles." 39

But now we can go behind the story and check it. Dr Ruth Coggan has kindly sent me fuller details, in her own handwriting, on a Pakistani airletter postmarked "Bannu 26 July 82." The relevant portion reads (for sake of clarity abbreviations have been spelt out) as follows.

\section{Case 3}

"Kamro was Para 7 aged about 35 was first seen by me on 13 May 1982 at about eight months gestation (you will be amused at the vagueness of all these estimates!) complaining of bleeding on and off for five months, with intermittent abdominal pain. She was urged to come in to hospital but only did so on 15 May, after very heavy loss the preceding night. On examination blood pressure $170 / 110 \mathrm{~mm} \mathrm{Hg}$. Marked oedema of feet and abdominal wall. Haemoglobin $78 \%$. Uterus size about 32/40 longitudinal lie, head very high and poorly palpable. Adrnitted for supervised rest and blood pressure settled to $160 / 100 \mathrm{~mm} \mathrm{Hg}$, but on day after admission had another very heavy bleed. Low segment caesarean section. Unfortunately I was completely unable to locate any cerebrospinal fluid to put in a spinal anaesthetic as I usually do, so I did the operation under local infiltration of $1^{10}$.) lignocaine plus intravenous pethidine, $100 \mathrm{mg}$ altogether. A low transverse incision in the lower uterine segment went right through the placenta which was found to be extremely adherent to the lower uterine flap and was raggedly removed. Copious dark blood was released on entering the uterus. A $2.3 \mathrm{~kg}$ female child-who thrived. (I'm afraid I have no note about the absence or presence of retroplacental clot, but the placenta was pretty chewed up by the time I had incised it and removed the adherent bits.) Heavy blood loss at time of operation and profuse loss post operatively-not clotting. Deep pools of unclotted blood between the patient's thighs and pad-heavy and prolonged trickling. Oxytocin was added to the dextrose saline drip, and then we prayed with the patient after explaining to her about Jesus in whose name we had prayed for her before the operation, and who was a great healer. I also told her that we were not going to worry. I had seen Jesus heal this condition before and was sure He was going to heal her. We then managed to get 2 pints blood for her-brisk bleeding continued. First clot was seen 48 hours after operation. Heavy loss had continued till then but her general condition gave no cause for concern after the initial postoperative examination at two hours. We prayed again with her on the night of the operation and then to thank Jesus for her healing when she went home with her baby on the 10th day. It is a privilege and thrill to be able to take part in the Lord's work of healing and see Him at work." (Ruth Coggan, FRCOG, personal communication.)

We need have no doubt as to the accuracy of the diagnosis or clinical details. There is no way of measuring Kamro's total blood loss but it seems probably that she lost more than her total blood volume during the 48 hours before clotting occurred. Dr Coggan is a member of the Church Missionary Society, and-a bonus from the viewpoint of this paper-her father was 93rd in the succession of bishops and archbishops of York which started in the seventh century with Paulinus and Wilfrid.

This story, which the normal techniques of historical scholarship would almost certainly have caused us to dismiss, has become impressive because we are in a position to question the person concerned. As we are unable to question those present at the miracles in the sixth and seventh century we must attempt to match them with similar cases in the twentieth century which we can investigate.

\section{Case of workman who fell while building God's house}

Falls during building operations must have been common. Skeletal evidence of the gross deformities which could result have been published by Wells. ${ }^{40}$ During the construction of the church at Hexham, one of the bishop's masons fell from a great height, broke his arms and legs, and dislocated his joints. He lay gasping his last. "Wilfrid had been praying and weeping but now hastily summoned all the workmen. 'Let us show how great our faith is by praying together with one accord that God may send back the soul into this lad's body and hear our prayers for his life, even as he heard the prayers of St Paul. 'They knelt and prayed that he who mocks at every good thing might have no victory to gloat over in this building. The bishop prayed after the manner of Elijah and Elisha and gave his blessing. The breath of life returned to the boy. The doctors bound up his arms and legs and he improved steadily day by day. He is still alive to give thanks to God and his name is Bothelm."

There are five facets to this story: the building of God's house, the workman's fall with skeletal injuries, the sense that God's honour was at stake, communal prayer, and the cure. Those same factors are present in the case recorded by Mother Basilea Schlink of the Evangelical Sisters of Mary, a Lutheran order in West Germany. She reports the building of their mother house and chapel in 1951 by their own nuns, despite the forebodings of sceptics. 


\section{Case 4}

"We had ventured out, trusting in God alone, and for His glory. According to our inner guidance we had not taken out accident insurance, or any other kind of insurance. Would God now permit some accident or mishap ?" A sister fell on a freshly cemented floor on the second storey. She broke through and to make it worse fell right on the edge of a piece of lumber. She was taken to the hospital. The $x$ ray film showed a compound fracture of the pelvis. "This brought us low before God. ... After a night of prayer-fraught with the worse temptations-I struggled through to a clear conviction: this accident had not been given in order to test us through a long time of suffering, rather it would serve to glorify God through a healing. It was then a matter of obedience to God's command. We did it, neverthe less, with trembling hearts. It was a great responsibility. The fearful question hung over our heads: what if she should become a cripple for the rest of her life ? According to medical advice she should have remained in traction for many weeks. We were taking her home after only two days. I had to sign for her release, accepting full responsibility. The doctor in charge spoke very earnestly to me, 'Mental sicknesses may perhaps be healed by prayer, but prayer will never mend a broken bone,' he warned me strongly.

At home Mother Martyria and I laid our hands on the sister and prayed. Some of the other sisters stood by and praised the victorious name of Jesus. The sister stood up from her bed. She had not been able to move on her bed without excruciating pain, and now she could actually stand on her feet. We looked at her, and for some moments could hardly take our eyes from her. Then we bowed in wonder and adoration before God-a God who indeed works miracles. Within two weeks the sister was completely healed, and presented herself to the doctor. The story spread through the country like wildfire. It magnified God's glory far more than if $\mathrm{He}$ had protected us from danger and accidents the whole time." "42 In response to inquiries, I received a letter with the words "to the glory of God we can confirm these events as eye witnesses" (Sister Ruth, personal communication). Further inquiries elicited the reply that the sister had walked without any limp (Sister Eulalia, personal communication).

The miraculous healing of Sister EL at Darmstadt was published not more than 15 years after it occurred, when there must have been a host of people (as there still are) with personal knowledge able to refute the story if it were inaccurate. The accident to Bothelm must have occurred in the 670s, and Eddius's account was written some 40 years later. ${ }^{41}$ As we know the subject of the miracles was still alive, it is a fair assumption that a number of his friends were available to comment on the record. If we accept Mother Basilea there appears no valid reason to reject Eddius out of hand.

\section{Undiagnosed unilateral pain beyond medical help}

Bede records (Vita $S$ Cuthberti: 30 ) another miracle testified to by many eye witnesses among whom there is the holy priest Aethilwald, one of Cuthbert's retinue at the time and now abbot of Melrose. Cuthbert was making his usual preaching mission through the villages and had come to one where there were a few nuns. ... One of them, a relation of Aethilwald, was seriously ill, seized with pains in the head and all down one side, so that the doctors had given her up. Cuthbert's companions pointed this out to him and begged him to heal her. Full of pity for her wretchedness he annointed her with holy oil. She began to improve from that very moment and in a few days completely recovered. ${ }^{15}$

\section{Case 5}

In 1976 a group of four Christians, three expatriate missionaires and a national carpenter, travelled to a remote part of Nepal to start a new leprosy clinic. While erecting a chimney stack, the missionary builder fell on to a metal pipe on the upper verandah and then rolled off and fell 10 feet on to a concrete parapet. The missionary doctor was with him. Mr P had obviously hurt his left side and at first was thought to have fractured his ribs. His blood pressure fell, his pulse rose, his abdomen became rigid and silent, and it became obvious that he was suffering from intra-abdominal haemorrhage from a rupured spleen. The party had just arrived, the medical supplies were as yet unpacked, and in any case did not contain surgical equipment. The doctor was able to give him morphine and set up a saline intravenous infusion. They sent a police message for help which never got through and there were no human resources left.

After two hours the patient asked for prayer and anointing with oil. The four Christians gathered round. They read the Biblical injunction together. "Is any sick among you ? Let him call for the elders of the church; and let them pray over him, anointing him with oil in the name of the Lord: and the prayer of faith shall save the sick, and the Lord shall raise him up." 43 Cooking oil was employed for anointing. Though the drip soon stopped, his pulse and blood pressure rapidly improved. "We believe the Lord stopped the haemorrhage in response to prayer. We were alone in that situation for eight days. This time enabled us to integrate into that remote local community, and the people saw for themselves the effects of our prayers." (Mary Thomson, personal communication.)

Although these two cases do not match in that the nun's pain was chronic ${ }^{44}$ they have in common the life threatening one sided pain, the inability if medical skill to help, and the anointing with oil. And the cure. The missionary builder concerned is still working in Nepal.

\section{The two stage healing of ulcers}

Bede in his homily on Luke ${ }^{45}$ records a story told him by one who lived near Jarrow Monastery. A woman, because of possession by an evil spirit, had contracted hideous ulcers. As long as she remained silent nothing could be done for her; but when she had told all that had happened she was cured by prayers and by application of holy salt, together with the doctor's medical aid. Only one stubborn ulcer remained, against which no remedies prevailed. At last, by her own suggestion, based on previous experience, oil blessed for the sick was applied, whereupon the remaining ulcer immediately responded to treatment by priest and doctor.

The points of interest in this story are the first step of ulcer healing after prayer, but final healing having to wait a second spiritual touch.

\section{Case 6}

About 1970 the captain of the Girls' Brigade at Enon Baptist Church, Monkwearmouth, had a deterioration in a large varicose ulcer of the leg which had been troubling her for many years. Each morning her bandage was soaked with pus. Her doctor told her to give up her activities. She asked for prayer at the monthly charismatic prayer meeting. A general practitioner present examined the leg and judged that even were the ulcer to heal, it would require skin grafting.

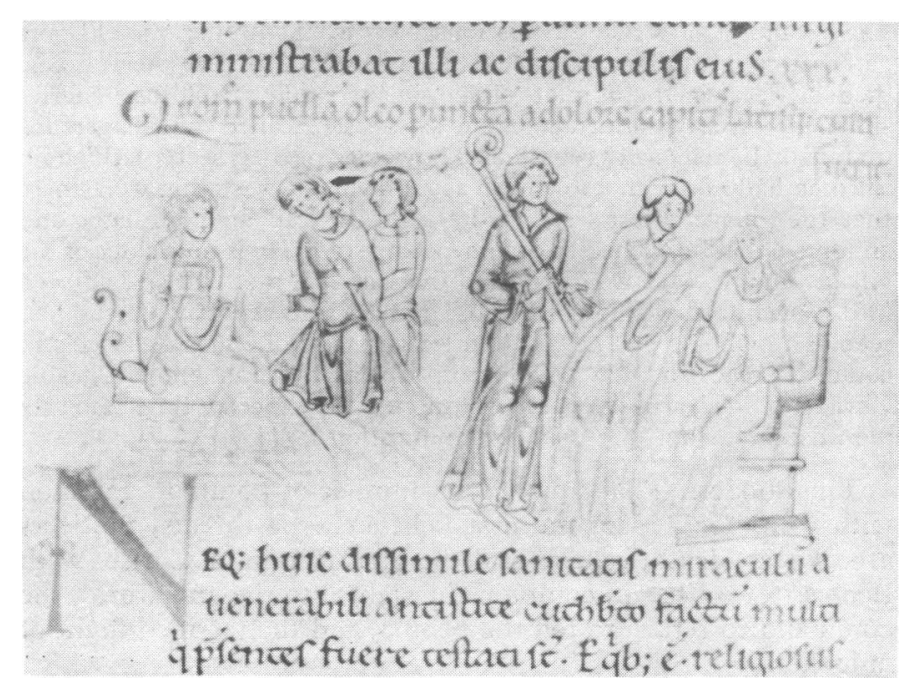

St Cuthbert cures the nun incurably ill with pain in the side, by anointing with oil. (Vita S Cuthberti: 30). University College, Oxford, MS165. Bodleian Library. (By permission of the Master and Fellows of University College.) 
The pastor requested one of the women present to join him in praying for the patient. By next morning almost the whole ulcer had dried up with healthy skin covering; but one spot continued to exude pus. One week later one of the Girls' Brigade lieutenants called on the pastor and with embarrassment stated that she felt she should have joined in the prayer for the patient. They immediately visited the patient and the lieuterant laid hands on the area and prayed. Healing became immediately complete. ${ }^{3 \times}$

This story is so bizarre that it would not have been included were I not one of the doctors who examined the patient's leg at the next monthly prayer meeting, and were not all the people who had been present available for interrogation. Against the background of such cases one can no longer shrug off the miracles of the sixth and seventh centuries.

\section{Return from the dead}

Bede tells us (Historian Ecclesiasticum Gentis Anglorium 5:12) of a religious man who died in the early hours of the night. But next dawn he came to life again and suddenly sat up so that all who were sitting mourning around his corpse were terrified and fled, except his wife who loved him dearly and remained with him though trembling with fear. Her husband comforted her saying, "Do not be afraid, for I have indeed risen from death which held me in its bonds, and I have been permitted to live again among mankind, nevertheless after this I must not live as I used to, but in a very different way." Which is not to be wondered at for he later recounted having been shown heaven and hell. ${ }^{21}$

Adomnan recounts (Life of Columba 2:32) a story in the life of Columba when he was working among the Picts. "A certain layman with his whole household heard, and believed the word of life. . . . and all were baptised. After the interval of a few short days a son of the house was seized by a severe illness and brought to the boundary of death and life. When the magicians (Druids ${ }^{16}$ ) saw that he was dying, they began to taunt his parents with great reproach." The boy died. Columba was informed, went to the house, prayed to Christ the Lord. "Rising from his knees he turned to the dead boy and said, 'In the name of the Lord Jesus Christ be restored to life and stand on thy feet'. . . The dead boy opened his eyes and lived again, and the God of the Christians was glorified."

\section{Case 7}

In $1963 \mathrm{Mr}$ Robin Talbot and his wife of the Overseas Missionary Fellowship were the first Christians to reside in the village of Still Water in the Mong tribal area of North Thailand. Mrs Ling, aged about 50 , was the first villager to destroy her domestic spirit shelf and become a Christian. The villagers warned her that ill would come of it. It did. She became sick. While the missionaries prayed with her, the villagers gathered round and watched while the village animist priest jeered. She died. At least in the opinion of the villagers and of the missionaries she died. Twenty minutes later she sat up. She called the villagers individually by name and revealed a knowledge of their secrets which up till then had not been known. So accurate and devastating were these that the village priest's son fled, to return half an hour later and announce that he wished to become a Christian. He is now elder of the village church. Mrs Ling reported that she had met Christ, had seen into heaven, but was told she must go back and report what she had seen. Though she had never attended any type of church service and could not read, she now gave proof of being a deeply knowledgeable Christian. She learnt to read in one month, the expected time being six months. (R Talbot, personal communication.)

This modern Thai story has a number of points in common with Columba's case: the first believers, the threats, the jeers at sickness, death, return, and the glorification of Christ. With Bede's story it has in common the sight into the afterworld, the command to return to tell the people, and the terrified flight of onlookers.

There is of course not the slightest proof that any of these people, Northumbrian, Pictish, or Thai, actually died. There are no electroencephalograms. But that does not affect the parallelism, nor its implication.

\section{Conclusion}

A number of case histories of "miraculous" healings in the past 30 years have been presented in which independent corrobation is possible. It is noteworthy that in most cases members of the British medical profession still in practice were actively taking part. No attempt has been made to prove that miracles have occurred, such proof being probably impossible. The adjective "miraculous" is, however, permissible as a convenient shorthand for an otherwise almost inexplicable healing which occurs after prayer to God and brings honour to the Lord Jesus Christ.

These cases have been paired with miracle stories recorded by Bede and his contemporaries, which up to now have not been considered historically admissible. They have normally been discarded as mere copies of New Testament incidents, or of prototype lives such as that of St Antony produced to add stature to a local saint." "Their writers have been excused as being merely those who put floating tradition into shape or who provided stories which not only delighted the simple minded but filled them with awe and reverence. ${ }^{17}$ It is my contention that we can now treat their writings with even greater respect than has up to now been possible. They, and the saints whose lives they portray, prove to be men of greater stature than we have hitherto believed.

It has often been noted that in his Lives of the Holy Abbots of Wearmouth and farrow Bede included no miracles. ${ }^{4 *}$ This has been explained on the grounds that while elsewhere he was writing as hagiographer here he was writing as historian, ${ }^{21}$ that "upon home ground and with local records at hand, Bede chose to be altogether realistic." "But the anonymous author of the parallel Life of Coelfrith, while noting a miracle as occurring in France at Coelfrith's tomb in Langres, likewise fails to record any such event in his home monasteries on Wearside. ${ }^{4 "}$

Hunter Blair makes the point ${ }^{51}$ that as a theologican Bede reflects in his commentaries the contemporary theological belief that in the days of the miraculous, necessary in the earliest times of the church, were now largely past. A detailed study provided by Kelsey, ${ }^{51}$ of expectations of divine healing in the early church, shows that it was in the pontificate of Gregory the Great that such were felt to be past. It is certainly clear from Gregory's response (Historiam Ecclesiasticum Gentis Anglorium 1:31) to news of the healing of a blind girl by Augustine in the earliest days of the Roman mission to Kent, that such were not encouraged. ${ }^{15}$

The simplest explanation appears to be that, being no longer expected or even welcome, miracles no longer occurred in Bede's lifetime in Jarrow or Monkwearmouth. That the days of miracles are past is a belief still shared by many Christians. ${ }^{52}$ In their experience, therefore, no such incidents occur as those reported here. In the latter part of the twentieth century, however, there is now an increasing number whose experience and expectations are more in accord with those of Cuthbert.

I am grateful to Dr Helen Cayton for introducing me to AngloSaxon medicine, to Mr R C Norris, deputy librarian, Dean and Chapter Library, Durham, to Mr M Strachan, medical photographer, and to Mrs F Hair, medical librarian, for their help.

\section{References}

1 Collingwood WG. Northumbrian crosses of the pre-Norman age. London Faber, 1927:19-26.

2 Hope-Taylor S. Yeavering: an Anglo-British centre of early Northumbria. London: HMSO, 1977.

${ }^{3}$ Backhouse J. The Lindisfarne gospels. Oxford: Phaidon Press, 1981.

${ }^{1}$ Lightfoot JB. Leaders in the northern church. London: Macmillan, 1891.

${ }^{5}$ Meissner JLG. The Celtic church in England after the Synod of Whitby. London: Hopkinson, 1929.

${ }^{6}$ Mayr-Harting H. The coming of Christianity to Anglo-Saxon England. London: Batsford, 1972.

' Anderson AO, Anderson MO. Adomnan's life of Columba. 1:27. Edinburgh: Nelson, 1961.

* Payne JF. English medicine in the Anglo-Saxon times. Oxford: Oxford University Press, 1904. 
${ }^{9}$ Rubin S. The medical practitioner in Anglo-Saxon England. $f R$ Coll Gen Pract 1970;20:63-71.

10 Highfield JA. Miracles concerning death in old English hagiography. Exeter: University of Exeter, 1978. Thesis.

11 Loomis CG. Hagiological healing. Bull Hist Med 1940;8:636-41.

12 Ward B. Miracles and history: a reconsideration of the miracle stories used in Bede. In: Bonner G, ed. Famulus Christi: essays in commemoration of the 13th centenary of the birth of the Venerable Bede. London: Society for the Propagation of Christian Knowledge, 1976:70-6.

${ }^{13}$ Raine J. Saint Cuthbert: with an account of the state in which his remains were found upon the opening of his tomb. Durham: Andrews, 1828.

14 Loomis CG. The miracle traditions of the Venerable Bede. Speculum $1946 ; 21: 404-18$.

15 Webb JF. Bede's life of Cuthbert. In: Farmer DH, ed. The age of Bede. Harmondsworth: Penguin, 1983:39-102.

${ }^{16}$ Whiting CE. The life of the Venerable Bede. In: Thomson AH, ed. Bede. His life times and writings. Essays in commemoration of the twelfth century of his death. Oxford: OUP, 1935:1-38.

${ }^{17}$ Neumann H. Jutish burials in the Roman iron age. In: Evison VI, ed. Angles Saxons and Futes: essays presented to f N L Myers. Oxford: OUP, $1981: 1-10$

${ }^{18}$ Mackay TW. Bede's hagiographic method. His knowledge and use of Paulinus of Nola. In: Bonner G, ed. Famulus Christi. London: SPCK, 1976:77-92.

19 Wallace-Hadrill JM. Bede and Plummer. In: Bonner G, ed. Famulus Christi. London: SPCK, 1976:366-85.

${ }^{20}$ Colgrave B. Bede's miracle stories. In: Thompson AH, ed. Bede: his life times and writings. Oxford: OUP, 1935:201-29.

21 Colgrave B, Mynors RAB. Bede's ecclesiastical history of the English people. Oxford: OUP, 1969.

22 Ray R. Bede's “Vera Lex Historiae." Speculum 1980;55.1:1-21.

${ }^{23}$ Markus RA. Bede and the tradition of ecclesiastical historiography. Jarrow Lecture 1975. Jarrow: St Paul's Church, 1976.

${ }^{24}$ Meyvaert P. Bede the scholar. In: Bonner G, ed. Famulus Christi. London SPCK, 1976:40-69.

${ }^{25}$ Bonser W. The Medical background of Anglo-Saxon England. London Wellcome Historical Medical Library, 1963.

26 The Holy Bible. Gospel of John. vii, 23.

27 Finlay J. Columba. London: Gollancz, 1979.

${ }^{28}$ Ranger T. Introduction. In: Sheils $\mathrm{WJ}$, ed. The Church and healing: papers read at the twentieth summer meeting and the twenty first winter meeting of the Ecclesiastical History Society. Oxford: Blackwell, 1982: i-xii.

${ }^{29}$ Brunner FD. A theology of the Holy Spirit. London: Hodder and Stoughton, 1976.
30 Ranaghan K, Ranaghan D. Catholic pentecostals. Paramus, NJ: Paulist Press, 1969.

31 Wilkinson J. Health and healing. Edinburgh: Handsel Press, 1980.

${ }^{32}$ Maddocks M. The Christian healing ministry. London: SPCK, 1981.

${ }^{33}$ Mews S. The revival of spiritual healing in the Church of England 1920-26. In: Sheils WJ, ed. The Church and healing. Oxford: Blackwells, $1982: 229-331$.

34 MacNutt F. Healing. Notre Dame: Ave Maria Press, 1974.

${ }^{35}$ Church of Scotland. Report of panel of doctrine to the General Assembly. $V$ : the charismatic movement within the Church of Scotland. Edinburgh Church of Scotland, 1974:167-85.

${ }^{36}$ Plummer C. Introduction to Bedae Opera Historica. Oxford: OUP, 1896 ix-lxxix.

${ }^{37}$ Harper M. As at the beginning: the twentieth century pentecostal revival. London: Hodder and Stoughton, 1965.

${ }^{38}$ Bridge D, Phypers D. More than tongues can tell. London: Hodder and Stoughton, 1982.

39 Stenton FM. Anglo-Saxon England. 2nd ed. Oxford: OUP, 1947.

40 Wells C. Une fracture rare chez un ancien Anglo-Saxon. Helium 1975;15 237-43.

${ }^{41}$ Webb JF. Eddius Stephanus' life of Wilfrid. In: Farmer DH, ed. The age of Bede. Harmondsworth: Penguin, 1983:105-84.

${ }^{42}$ Schlink B. Realities: the miracles of God experienced today. London Marshall, 1967.

43 The Holy Bible. Epistle of James. v, 14-15.

44 Anonymous. Anonymous life of S Cuthbert. In: Colgrave B, ed. Two lives of St Cuthbert. Cambridge: Cambridge University Press, 1940:4 iv.

45 Bede. Opus XI, 76. Quoted in Duckett ES. Anglo-Saxon saints and scholars. New York: Macmillan, 1974.

${ }^{46}$ Huyshe W, translator. Adamnan: life of St Columba. London: Routledge, 1908.

47 Colgrave B. The earliest saints lives written in England. Proceedings of the British Academy 1958;44:35-60.

48 Bede's lives of the abbots of Wearmouth and Jarrow. In: Farmer DH, ed. The age of Bede. Harmondsworth: Penguin, 1983:183-208.

49 Anonymous life of Coelfrith, Abbot of Jarrow. In : Whitelock D, ed. English historical documents. Vol 1. London: Eyre and Spottiswoode, 1979: 697-707.

50 Blair PH. Bede's ecclesiastical history of the English nation and its importance today. Jarrow lecture, 1959. Jarrow: St Paul's Church, 1960.

${ }^{51}$ Kelsey MT. Healing and Christianity in ancient thought and modern times. London: SCM, 1973.

52 Warfield BB. Counterfeit miracles. London: Banner of Truth, 1972.

के

急

$\widehat{\overparen{\Omega}}$

赵

m

票

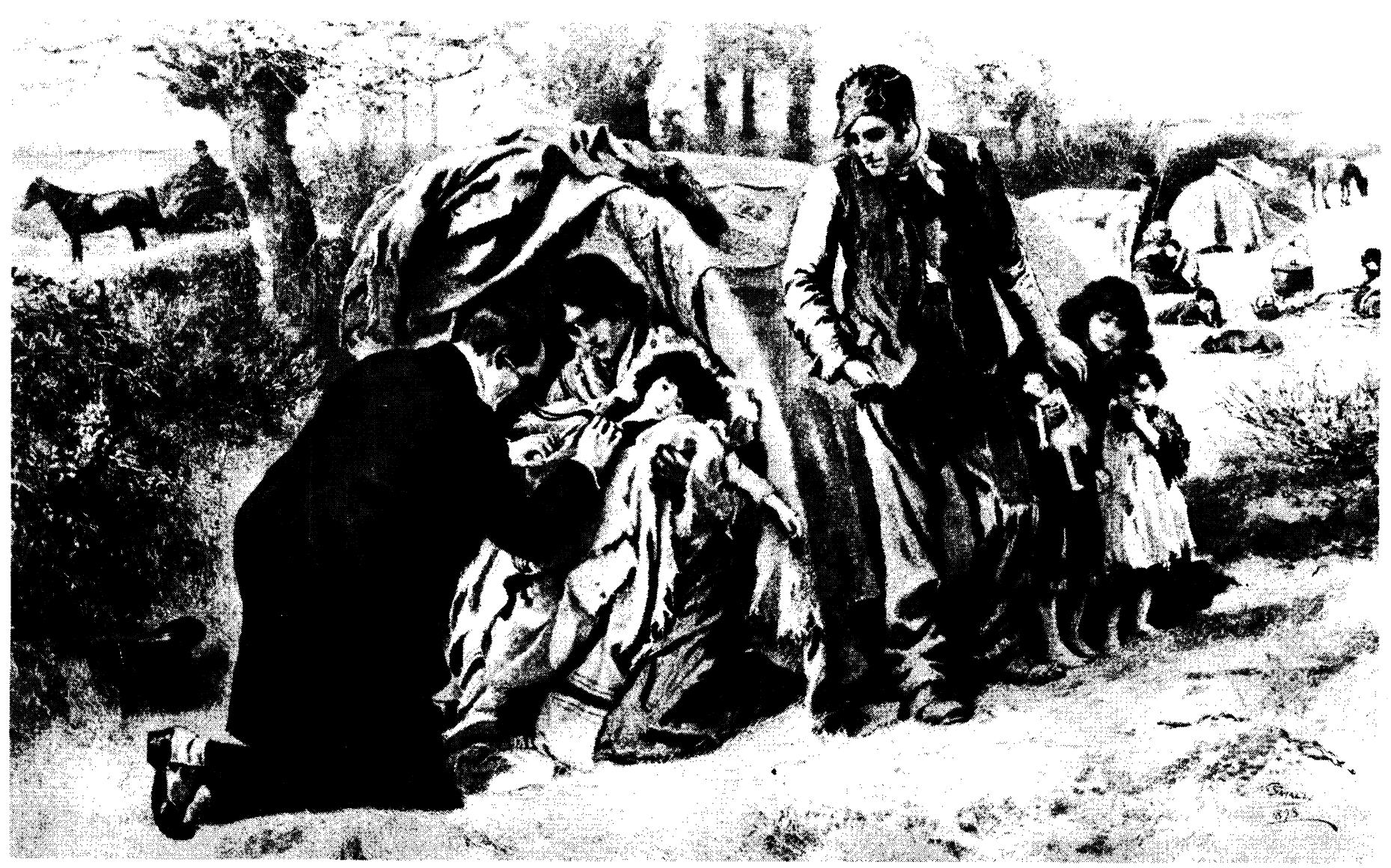

The good Samaritan, by W Small, 1898. 